Article

\title{
Synthesis and Molecular Descriptor Characterization of Novel 4-Hydroxy-chromene-2-one Derivatives as Antimicrobial Agents
}

\author{
Milan Mladenović *, Nenad Vuković, Neda Nićiforović, Slobodan Sukdolak and Slavica Solujić \\ Department of Chemistry, Faculty of Science, University of Kragujevac, P.O. Box 60, Serbia; \\ E-mails: nvukovic@kg.ac.rs (N.V.),nneda@kg.ac.rs (N.N.),duda@kg.ac.rs (S.S.), \\ ssolujic@kg.ac.rs (S.S.)
}

* Author to whom correspondence should be addressed; E-mail: mmladenovic@kg.ac.rs.

Received: 25 February 2009; in revised form: 26 March 2009 / Accepted: 7 April 2009 /

Published: 14 April 2009

\begin{abstract}
Several novel 4-hydroxy-chromene-2-one derivatives $\mathbf{2 b - 1 6 b}$ were easily prepared through condensation reactions with microwave heating and characterized by elemental analysis, IR, ${ }^{1} \mathrm{H}-\mathrm{NMR}$ and mass spectrometry. Geometry optimization of these compounds was executed by PM3, PM5 and Minimize Energy methods to describe them via molecular descriptors. The antimicrobial activity of the synthesized compounds was evaluated against different microbial strains using two different methods: the diffusion method and the micro-dilution method. All data indicated that the products possess antimicrobial activity which depends on the nature of substituent attached to the benzopyran moiety. In general, after $24 \mathrm{~h}$ the MIC values of most tested coumarins was $0.13 \mathrm{mg} / \mathrm{mL}$, but compounds $\mathbf{1}$ and $\mathbf{6 b}$ displayed the strongest antimicrobial activity on the tested cultures of bacteria after $48 \mathrm{~h}$. Compound 13b has the strongest growth inhibitory potential on fungus $C$. albicans, tested by diffusion method, with an inhibition zone of 30$37 \mathrm{~mm}$ at a concentration of $150 \mu \mathrm{g} / \mathrm{mL}$. The conclusion of this experiment is that the synthesized compounds have varied and different influence on different classes of bacteria and the fungus $C$. albicans.
\end{abstract}

Keywords: Coumarins; Microwave synthesis; Molecular descriptors; Antimicrobial activity. 


\section{Introduction}

Coumarins are benzopyran derivatives. Naturally occurring coumarins have been isolated from over 800 species of plants and microorganisms [1], and many of these natural products exhibit useful druglike activity [2,3]. Moreover, coumarins are a group of compounds that play important roles as food constituents, antioxidants, stabilizers and immunomodulatory substances, as fluorescent markers for use in analyses, in stains, and in clinical use [4,5]. Coumarins possess anti-inflammatory, antiallergic, hepatoprotective, spazmolitic, antiviral, anticarcinogenic and anticoagulant activities [6]. They also constitute an important group of organic compounds that are used as additives to cosmetics, as optical brightening agents, and dispersed fluorescent and laser dyes [7-9]. Coumarins also have important effects in plant biochemistry and physiology, acting as enzyme inhibitors and precursors of toxic substances. In addition, these compounds are involved in the actions of plant growth hormones and growth regulators, the control of respiration, photosynthesis, as well as defense against infection [10]. These natural aromatic compounds exhibit enormous structural variability, due to the various types of substitutions in their basic structure possible, which in turn can influence their biological activity.

The first reports of the application of commercial microwave ovens to the synthesis of small organic molecules appeared in 1986. [11,12]. Microwave irradiation has since been proven to be extremely useful for promoting and simplifying many condensation reactions which can be carried out both in solvents and under solvent-free conditions [13-17]. Microwave technology is particularly suitable for the rapid and automated production of libraries of compounds, as it enables organic chemists to reduce the time of synthesis from days and hours to minutes and even seconds [18-20]. In addition, suppressed formation of side-products and improved yields under microwave heating conditions has frequently been observed. Finally, the proper choice of microwave processing techniques (solvent-free, solid- or polymer-supported conditions) can simplify the workup and avoid laborious and time-consuming purification of target compounds.

The essence of this work was synthesis of coumarin derivatives using microwave irradiation, in comparison with conventional methods. Coumarin derivatives have previously been studied in our laboratory [21-26]. We have now extended these studies to investigate their structural modification through Knoevenagel condensations carried out under microwave irradiation and leading to several 4hydroxychromene-2-one derivatives. We also report a conventional and convenient microwavepromoted solution synthesis of eight imino derivatives of 4-hydroxychromene-2-one. All the reactions performed were monitored by TLC and GC/MS and yields were determined using the latter technique.

The use of solvent-free conditions for the fast synthesis of novel coumarin derivatives by the Knoevenagel condensation under microwave irradiation offers several advantages [27]: solvents are often expensive, toxic environmental polluting agents, and in the case of aprotic dipolar solvents with high boiling points, difficult to remove. Moreover, liquid-liquid extraction for the isolation of reaction products can be avoided, and the absence of solvent also avoids the risk of hazardous explosions when the reactions take place in a microwave oven. The workup procedure is reduced to the simple recrystallization of products from an appropriate solvent. The classical organic synthesis of imine derivatives commonly faces the problems of low yields, reaction byproducts, removal of solvents from reaction mixtures or liquid extraction, especially in the case of aprotic dipolar solvents with high boiling points, or product isolation through liquid-liquid extraction. In contrast to the classical method 
microwave irradiation often leads to a remarkable decrease in the reaction times and increased yields (in our case up to 98\%). The products could be purified simply by recrystallization from an appropriate solvent or mixture of solvents. The synthesized coumarin derivatives were tested as antimicrobial agents by the disc-diffusion and MIC methods on some Gram positive and Gram negative bacteria and the fungus C. albicans.

\section{Results and Discussion}

\subsection{Synthesis}

Preparations of coumarin derivatives $\mathbf{2 b - 8 b}$ by the conventional condensation method were characterized by lower yields of the desired compounds (no more than $32 \%$ ), followed by time consuming purifications by column chromatography. Thus, we report herein substantial improvements to the synthesis of these compounds using a solvent free microwave promoted reaction. The obtained results indicated significant yield increases (up to 87\%), decreases in reaction times and, as far as purification of products is concerned, requiring only recrystallization from appropriate solvents.

Also, in a case of synthesis of imino derivatives of 4-hydroxychromene-2-one (1) microwave heating provided several advantages compared to the conventional method of preparation by azeotropic water removal. Due to homogenous heating achievable under microwaves side reactions

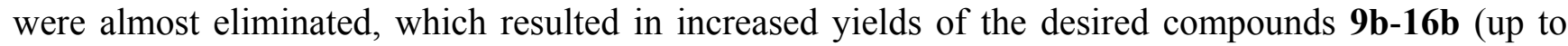
90\%). Additionally purifications were limited to only recrystallization from methanol, without requiring time and solvent consuming column chromatography.

Both elemental and spectral (IR, ${ }^{1} \mathrm{H}-\mathrm{NMR}$, mass spectra) analysis data of all compounds were in full agreement with the suggested molecular structures. The IR spectra of pure products $\mathbf{2 b - 8 b}$ indicated the presence of a broadened $\mathrm{OH}$ band in the $3437-3422 \mathrm{~cm}^{-1}$ region, corresponding to the hydroxyl fragment of the coumarin moiety. A strong coumarin moiety lactone $\mathrm{C}=\mathrm{O}$ band at 1706-1699 $\mathrm{cm}^{-1}$ was also observed. Synthesized compounds $\mathbf{2 b}, \mathbf{3 b}, \mathbf{4 b}$ and $\mathbf{5 b}$ possess additional strong $\mathrm{C}=\mathrm{O}$ bands from ester COOMe or COOEt groups at 1731-1729 $\mathrm{cm}^{-1}$. Additional acetyl group $\mathrm{C}=\mathrm{O}$ bands were observed at $1700-1686 \mathrm{~cm}^{-1}$ for compounds $\mathbf{3 b}, \mathbf{6 b}$ and $\mathbf{8 b}$. The IR spectra of compounds $7 \mathbf{b}$ and 8b showed broadened $\mathrm{OH}$ bands at 3111 and $3100 \mathrm{~cm}^{-1}$ and $\mathrm{C}=\mathrm{O}$ bands at $1699-1689 \mathrm{~cm}^{-1}$ from $\mathrm{COOH}$ groups. Strong absorptions in the $2231-2229 \mathrm{~cm}^{-1}$ region indicated the presence of $\mathrm{C} \equiv \mathrm{N}$ groups in the prepared compounds $\mathbf{5 b}$ and $\mathbf{7 b}$. The ${ }^{1} \mathrm{H}-\mathrm{NMR}$ spectra of compounds $\mathbf{2 b - 8 \mathbf { b }}$ showed the characteristic coumarin aromatic proton signals in the 7.83-7.29 ppm range (m, 4H, C-5-H, C-6-H, C7-H and $\mathrm{C}-8-\mathrm{H})$. All these spectra also contain resonances from methyl fragments $\left(\mathrm{C}=\mathrm{C}-\mathrm{CH}_{3}\right.$, singlet at 2.26-2.21 ppm) and hydroxyl groups (OH-4, broad singlet at 17.17-16.73 ppm). The protons of the methyl group from the COOMe fragment of compounds $\mathbf{3 b}, \mathbf{4 b}$ and $\mathbf{5 b}$ were observed as singlets at 3.86-3.81 ppm, while the compound $\mathbf{2 b}$ showed ethyl proton resonances at $4.21 \mathrm{ppm}\left(\mathrm{q}, 4 \mathrm{H}, \mathrm{CH}_{2}\right)$ and $1.23 \mathrm{ppm}\left(\mathrm{m}, 6 \mathrm{H}, \mathrm{CH}_{3}\right)$. In the vinyl proton region compound $\mathbf{4 b}$ showed an absorption at $5.76 \mathrm{ppm}(\mathrm{s}$, $\mathrm{C}=\mathrm{C}-\mathrm{H}$ ). Since the compounds $\mathbf{7 b}$ and $\mathbf{8 b}$ were prepared from acetic acid derivatives, broadened $\mathrm{OH}$ proton peaks were observed at low field (12.37 and $12.65 \mathrm{ppm}$, respectively). The methyl protons from the acetyl fragment of compounds $\mathbf{3 b}, \mathbf{6 b}$ and $\mathbf{8 b}$ were identified in the range of 2.29-2.26 ppm.

Formation of imine derivatives $9 \mathbf{b}-\mathbf{1 5 b}$ was evidenced by appearance of ${ }^{1} \mathrm{H}-\mathrm{NMR}$ signals in the aromatic protons region at 8.39-6.9 ppm and a strong $\mathrm{C}=\mathrm{N}$ group IR band at $1610-1606 \mathrm{~cm}^{-1}$. Also, all 
synthesized compounds showed $\mathrm{CH}_{3}-\mathrm{C}=\mathrm{N}$ proton resonances in the range of 2.81-2.61 pmm (s, $\mathrm{CH}_{3}$, $3 \mathrm{H})$. In the ${ }^{1} \mathrm{H}-\mathrm{NMR}$ spectrum of compound $\mathbf{1 6 b}$ a multiplet at $1.82 \mathrm{ppm}$ for a $-\mathrm{CH}_{2}-\mathrm{CH}_{2}$ - group, two triplets at $2.46 \mathrm{ppm}$ and $3.60 \mathrm{ppm}$ for a methylene protons from C'-4 and C'-1, respectively, and a broadened singlet from the hydroxyl group of $\mathrm{COOH}$ fragment at $11.3 \mathrm{ppm}$ were observed.

In Table 1 reaction conditions, substituents and yields of obtained compounds are presented. In Tables 2 and 3 molecular descriptors and side chain dihedral angles of the compounds that had been obtained by Mopac, CAChe and Spartan [28-30] software, are presented.

Compound 1, as a base for synthetic research, with compounds $\mathbf{6 b}$ and $\mathbf{1 3 b}$, were subjected to geometry examination since molecule planarity and voluminous side chain groups play important roles in the bioactivity of the compounds [31,32]. Geometries are presented in Figures 1-4. The presented compounds were selected based on results that confirm influence of planarity and substituent nature when coumarins penetrate bacterial cells [31,32].

Table 1. Reaction conditions, substituents and yields of obtained compounds $\mathbf{2 b - 8 b}$.

\begin{tabular}{|c|c|c|c|c|c|c|c|}
\hline \multirow{2}{*}{ No } & \multirow{2}{*}{$\mathbf{R}_{1}$} & \multirow{2}{*}{$\mathbf{R}_{2}$} & \multirow{2}{*}{$\mathbf{P w}(\mathrm{W})$} & \multirow{2}{*}{$\operatorname{Tm}(\mathrm{S})$} & \multirow{2}{*}{$\mathbf{T}^{\mathrm{a}}\left({ }^{\mathrm{o}} \mathrm{C}\right)$} & \multicolumn{2}{|c|}{ Yield (\%) } \\
\hline & & & & & & $\mathbf{A}$ & B \\
\hline $2 b$ & COOEt & COOEt & 500 & 7 & 123 & 27 & 96 \\
\hline $3 b$ & $\mathrm{COMe}$ & COOMe & 500 & 7 & 129 & 36 & 97 \\
\hline $4 b$ & $\mathrm{H}$ & COOMe & 500 & 9 & 121 & 18 & 96 \\
\hline $5 b$ & $\mathrm{C} \equiv \mathrm{N}$ & COOMe & 500 & 7 & 121 & 33 & 94 \\
\hline $6 b$ & COMe & COMe & 500 & 10 & 134 & 41 & 94 \\
\hline $7 b$ & $\mathrm{C} \equiv \mathrm{N}$ & $\mathrm{COOH}$ & 500 & 6 & 120 & 42 & 84 \\
\hline $8 b$ & $\mathrm{COMe}$ & $\mathrm{COOH}$ & 500 & 5 & 126 & 35 & 87 \\
\hline \multirow{2}{*}{ No } & \multirow{2}{*}{$\mathbf{R}_{3}$} & & \multirow{2}{*}{$\mathbf{P w}(\mathrm{W})$} & \multirow{2}{*}{$\mathbf{T m}(\min )$} & \multirow{2}{*}{$\mathbf{T}\left({ }^{\circ} \mathrm{C}\right)$} & \multicolumn{2}{|c|}{ Yield (\%) } \\
\hline & & & & & & $\mathbf{A}$ & B \\
\hline $9 b$ & $\mathrm{Ph}$ & & 500 & 3 & 109 & 75 & 95 \\
\hline $10 \mathrm{~b}$ & p-tolyl & & 500 & 3 & 109 & 73 & 97 \\
\hline $11 b$ & m-tolyl & & 500 & 3 & 109 & 84 & 94 \\
\hline $12 b$ & o-tolyl & & 500 & 3 & 109 & 73 & 94 \\
\hline $13 b$ & $\mathrm{p}-\mathrm{NO}_{2}$-phenyl & & 500 & 3 & 109 & 51 & 92 \\
\hline $14 b$ & $\mathrm{~m}-\mathrm{NO}_{2}$ - phenyl & & 500 & 3 & 109 & 62 & 97 \\
\hline $15 b$ & benzyl & & 500 & 3 & 109 & 75 & 97 \\
\hline $16 \mathrm{~b}$ & $\mathrm{C}_{4} \mathrm{H}_{9} \mathrm{COOH}$ & & 500 & 3 & 109 & 42 & 87 \\
\hline
\end{tabular}


Table 2. Molecular descriptors of observed compounds.

\begin{tabular}{|c|c|c|c|c|c|c|c|c|}
\hline \multirow[b]{2}{*}{ Parameters } & \multirow[t]{2}{*}{ Method } & \multicolumn{7}{|c|}{ Compounds } \\
\hline & & 1 & $\mathbf{3 b}$ & $4 b$ & $6 \mathbf{b}$ & $7 \mathbf{b}$ & $8 \mathbf{b}$ & $13 b$ \\
\hline Heat of Formation & PM3 & -120.57 & -184.38 & -149.91 & -140.02 & -119.39 & -193.17 & -20.97 \\
\hline \multirow[t]{2}{*}{$(\mathrm{kcal} / \mathrm{mol})$} & PM5 & -135.31 & -207.47 & -166.62 & -168.25 & -139.00 & -214.49 & -64.73 \\
\hline & SPARTAN(e.u) & 26.97 & 57.58 & 57.26 & 70.91 & 40.23 & 41.66 & 72.38 \\
\hline Electronic Energy (eV) & PM3 & -14412.18 & $-26955,66$ & $-21039,91$ & $-25237,76$ & $-22271,14$ & $-25448,75$ & $-27320,32$ \\
\hline Core-core Repulsion (EV) & PM3 & 11811.55 & 23083.21 & 17482.15 & 21395.99 & 18547.35 & 21441.45 & 23332.61 \\
\hline Gradient Norm & PM3 & 414.37 & 430.48 & 447.56 & 383.06 & 115.66 & 69.75 & 320.41 \\
\hline \multirow[t]{2}{*}{ Dipole (debye) } & PM3 & 7.32 & 4.99 & 7.25 & 6.11 & 6.54 & 4.96 & 9.94 \\
\hline & SPARTAN & 3.89 & 3.85 & 5.10 & 5.76 & 5.73 & 2.79 & 8.24 \\
\hline Symetry & SPATRAN & $\mathrm{C} 1$ & $\mathrm{C} 1$ & $\mathrm{C} 1$ & $\mathrm{C} 1$ & $\mathrm{C} 1$ & $\mathrm{C} 1$ & $\mathrm{C} 1$ \\
\hline No. of Fields Level & PM3 & 38 & 57 & 49 & 54 & 50 & 54 & 60 \\
\hline Ionization Potencial (eV) & PM3 & 9.70 & 9.41 & 9.34 & 9.34 & 9.67 & 9.50 & 9.59 \\
\hline Homo & \multirow{2}{*}{ PM3 } & -9.70 & -9.41 & -9.34 & -9.34 & -9.67 & -9.50 & -9.60 \\
\hline Lumo & & -1.26 & -1.30 & -1.37 & -1.30 & -1.59 & -1.31 & -1.45 \\
\hline Energies & \multirow{2}{*}{ SPARTAN } & -9.39 & -9.59 & -9.54 & -9.66 & -9.75 & -9.57 & -9.81 \\
\hline$(\mathrm{eV})$ & & 1.26 & -1.29 & -1.26 & -1.26 & -1.50 & -1.32 & -1.55 \\
\hline Molecular Weight & PM3 & 204.18 & 302.28 & 260.25 & 286.28 & 271.23 & 288.26 & 342.29 \\
\hline Scf Calculations & PM3 & 10 & 14 & 102 & 84 & 71 & 202 & 10 \\
\hline
\end{tabular}

Figure 1. PM5 geometry of 3-acetyl-4-hydroxy-chromene-2-one (1).

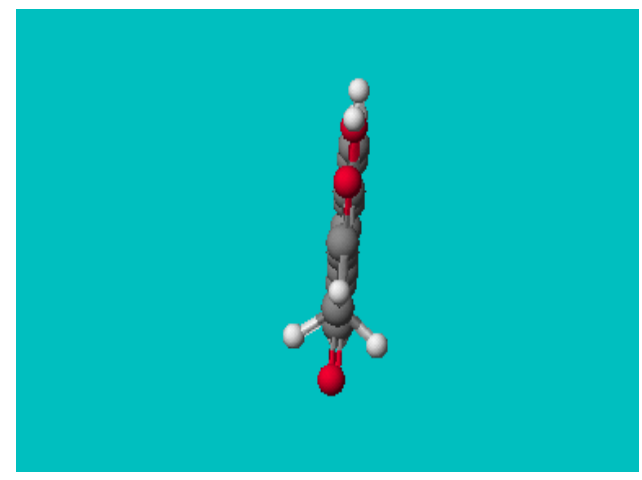

Figure 2. PM5 geometry of 3-(1-(4-hydroxy-2-oxo-2H-chromen-3-yl)-ethylidene)-pentane2, 4-dione (6b).

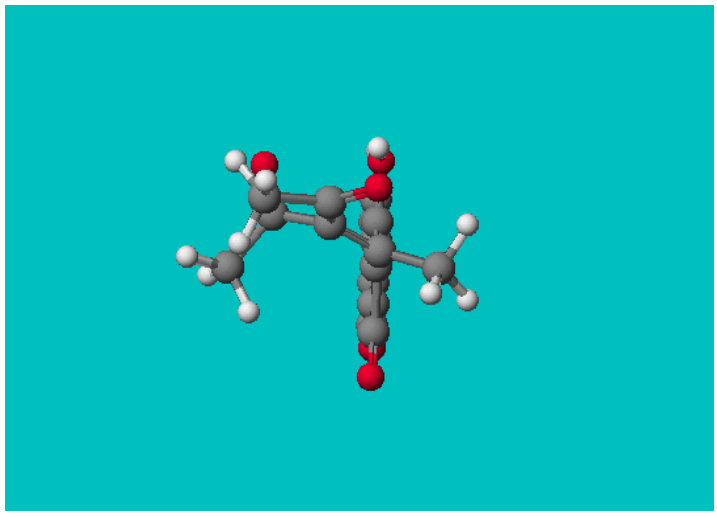


Figure 3. PM5 geometry of 4-hydroxy-3-(1-(4-nitrophenylimino)ethyl)-2H-chromen-2-one (13b).

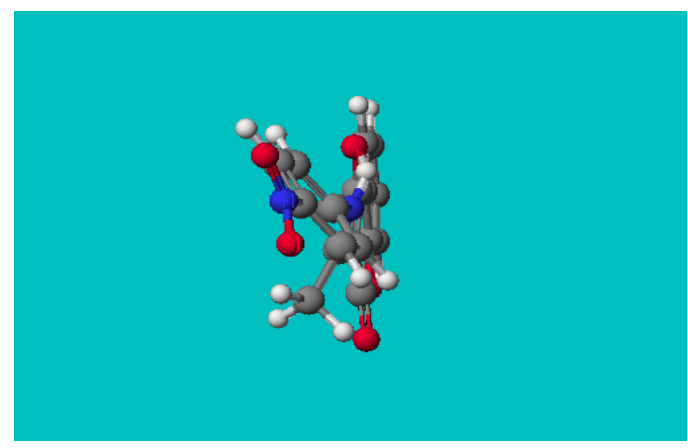

Figure 4. Spartan geometry of 4-hydroxy-3-(1-(4-nitrophenylimino)ethyl)-2H-chromen-2one (13b).

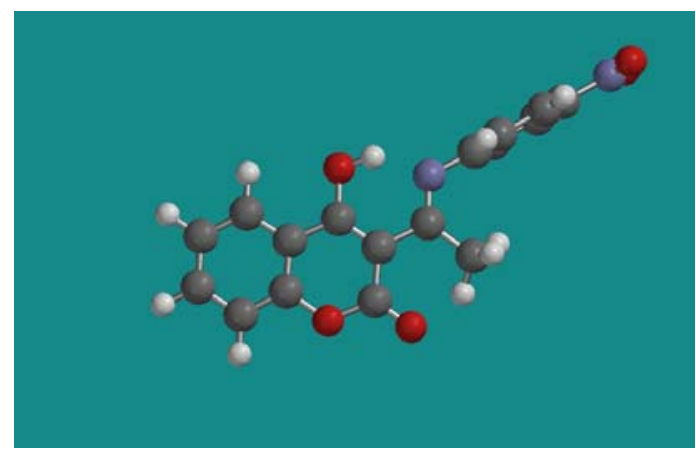

Table 3. Side chain atom angles of observed compounds.

\begin{tabular}{|c|c|c|c|c|}
\hline & $\begin{array}{c}\text { Side chain } \\
\text { atoms }\end{array}$ & $\begin{array}{c}\text { Angle } \\
\left({ }^{\circ}\right) \\
\end{array}$ & Dihedral atoms & $\begin{array}{c}\text { Dihedral } \\
\left({ }^{\circ}\right)\end{array}$ \\
\hline 1 & $-\mathrm{C}=\mathrm{C}-\mathrm{CO}$ & 120,67 & $\mathrm{C}$ (enol from ring) $\mathrm{C}=\mathrm{C}-\mathrm{CO}$ & 0,21 \\
\hline \multirow{3}{*}{$3 b$} & $-\mathrm{C}=\mathrm{C}-\mathrm{CO}$ & 122,43 & $-\mathrm{C}=\mathrm{C}-\mathrm{C}-\mathrm{O}$ & $-61,94$ \\
\hline & \multirow{2}{*}{$-\mathrm{C}=\mathrm{C}-\mathrm{COO}$} & \multirow{2}{*}{30,95} & $-\mathrm{C}=\mathrm{C}-\mathrm{C}-\mathrm{O}$ (carbonyl) & $-3,69$ \\
\hline & & & $-\mathrm{C}=\mathrm{C}-\mathrm{C}-\mathrm{C}$ (ester) & $-5,48$ \\
\hline \multirow{2}{*}{$4 b$} & $\begin{array}{c}-\mathrm{C}=-\mathrm{C} \text { (from ring)- } \\
\mathrm{C}(\mathrm{Me})\end{array}$ & 115,93 & $\begin{array}{c}\mathrm{C}=\mathrm{C} \text { (ring) }-\mathrm{C} \text { (side chain)- } \\
\mathrm{C}(\mathrm{Me})\end{array}$ & $-127,19$ \\
\hline & $-\mathrm{C}=\mathrm{C}-\mathrm{CO}$ & 126,44 & $\begin{aligned}-\mathrm{C} & =\mathrm{C}-\mathrm{C}-\mathrm{O}(\text { carbonyl }) \\
-\mathrm{C} & =\mathrm{C}-\mathrm{C}-\mathrm{C}(\text { ester })\end{aligned}$ & $\begin{array}{c}-134,44 \\
47,62\end{array}$ \\
\hline \multirow{2}{*}{$6 b$} & \multirow{2}{*}{$\mathrm{C}=\mathrm{C}-\mathrm{C}($ carbonyl $)$} & 121,79 & \multirow{2}{*}{$\mathrm{C}=\mathrm{C}-\mathrm{C}-\mathrm{O}$} & 88,86 \\
\hline & & 122,84 & & 15,34 \\
\hline \multirow[b]{2}{*}{$7 b$} & $\mathrm{C}=\mathrm{C}-\mathrm{CN}$ & 123,06 & $\mathrm{C}=\mathrm{C}-\mathrm{C}-\mathrm{C}$ (cyano) & 3,28 \\
\hline & $\mathrm{C}=\mathrm{C}-\mathrm{C}$ (carboxyl & 122,92 & $-\mathrm{C}=\mathrm{C}-\mathrm{C}-\mathrm{O}$ (carbonyl) & $-119,99$ \\
\hline \multirow{3}{*}{$8 b$} & $-\mathrm{C}=\mathrm{C}-\mathrm{CO}$ & 119,79 & $\begin{array}{c}-\mathrm{C}=\mathrm{C}-\mathrm{C}-\mathrm{O} \text { (ester) } \\
-\mathrm{C}=\mathrm{C}-\mathrm{C}-\mathrm{O} \text { (carbonyl) }\end{array}$ & $\begin{array}{l}61,05 \\
-54,78\end{array}$ \\
\hline & $\mathrm{C}=\mathrm{C}-\mathrm{C}($ carboxyl & 12168 & $-\mathrm{C}=\mathrm{C}-\mathrm{C}-\mathrm{O}$ (carbonyl) & 154,01 \\
\hline & acid) & 124,00 & $-\mathrm{C}=\mathrm{C}-\mathrm{C}-\mathrm{O}($ ester $)$ & $-30,51$ \\
\hline $13 b$ & $=\mathrm{C}($ from ring $)-\mathrm{C}=\mathrm{N}-$ & 122,79 & $\begin{array}{c}=\mathrm{C} \text { (from ring) }-\mathrm{C}=\mathrm{N}-\mathrm{C} \\
\text { (aromatic) }\end{array}$ & 180 \\
\hline
\end{tabular}




\subsection{Minimal Inhibitory Concentration}

All the reported compounds exhibited moderate in vitro activity against the tested bacterial strains (Tables 4 and 5) and the yeast C. albicans. Solutions of compound $\mathbf{1}$ for testing against S. aureus (isolate) were prepared in following concentrations: 0.94, 1.90, 3.80, 7.50, 15.00 and $30.00 \mathrm{mg} / \mathrm{mL}$. For other cultures tested the concentrations of compound 1 were $0.09,0.19,0.38,0.75,1.50$ and 3.00 $\mathrm{mg} / \mathrm{mL}$. For the rest of the compounds, the concentrations were: $0.125,0.25,0.50,1.00,2.00$ and 4.00 $\mathrm{mg} / \mathrm{mL}$. Tests were run in triplicate. Standards were tetracycline and ketoconazole (both at 0.500 $\mu \mathrm{g} / \mathrm{mL})$.

MIC values for all tested microorganism were in the range from $0.185 \mathrm{mg} / \mathrm{mL}$ to $2 \mathrm{mg} / \mathrm{mL}$, and results were read after $24 \mathrm{~h}$ and $48 \mathrm{~h}$ respectively. After $24 \mathrm{~h}$, with MICs of 0.09 (compound 1) and $0.13 \mathrm{mg} / \mathrm{mL}$ (compounds 3b-13b), no bacterial growth was visible in test tubes containing S. aureus, indicates that all seven compounds are good growth inhibitors of this species. Some compounds were less effective on the same culture isolated from tissue and towards M. lysodiekticus, and they stopped the growth at a concentration of $0.50 \mathrm{mg} / \mathrm{mL}$. After 48 hours, none of applied compounds stopped growth of S. aureus (isolate) or M. lysodiekticus, and a change of the indicator's color was visible. Tested bacteria were most sensitive to the compound $\mathbf{1}$, one with no substituent, and $\mathbf{6 b}$, which contains two acetyl groups. Carboxyl, ester and cyano derivatives demonstrated slightly lower activity.

Table 4. MIC values $(\mathrm{mg} / \mathrm{mL})$ of the synthesized coumarin derivatives.

\begin{tabular}{cccccccccccc}
\hline & \multicolumn{10}{c}{ Cultures } \\
\cline { 2 - 13 } & \multicolumn{9}{c}{ S. aureus } & \multicolumn{1}{c}{$\begin{array}{c}\text { S. aureus } \\
\text { (isolate) }\end{array}$} & \multicolumn{2}{c}{ M. } \\
lysodiekticus & \multicolumn{2}{c}{ E. coli } & \multicolumn{2}{c}{ C. albicans } \\
Comp. & $24 \mathrm{~h}$ & $48 \mathrm{~h}$ & $24 \mathrm{~h}$ & $48 \mathrm{~h}$ & $24 \mathrm{~h}$ & $48 \mathrm{~h}$ & $24 \mathrm{~h}$ & $48 \mathrm{~h}$ & $24 \mathrm{~h}$ & $48 \mathrm{~h}$ \\
\hline $\mathbf{1}$ & 0.09 & 0.19 & 0.94 & 1.90 & 0.19 & 0.38 & 0.19 & 0.38 & 0.09 & 0.09 \\
$\mathbf{3 b}$ & 0.13 & 0.50 & 0.50 & 1.00 & 0.13 & 0.50 & 0.13 & 0.50 & 0.13 & 0.50 \\
$\mathbf{4 b}$ & 0.13 & 0.50 & 0.50 & 1.00 & 0.13 & 0.50 & 0.13 & 0.50 & 0.25 & 0.50 \\
$\mathbf{6 b}$ & 0.13 & 0.25 & 0.13 & 0.50 & 0.50 & 0.50 & 0.25 & 1.00 & 0.13 & 0.25 \\
$\mathbf{7 b}$ & 0.13 & 1.00 & 0.50 & 0.50 & 0.13 & 0.50 & 0.50 & 1.00 & 0.50 & 1.00 \\
$\mathbf{8 b}$ & 0.13 & 0.50 & 0.50 & 1.00 & 0.13 & 0.50 & 0.13 & 0.50 & 0.13 & 0.13 \\
$\mathbf{1 3 b}$ & 0.13 & 0.50 & 0.13 & 0.50 & 0.50 & 0.50 & 0.13 & 0.50 & 0.13 & 0.13 \\
\hline
\end{tabular}

The lowest sensitivity, only for S. aureus, was displayed by the derivative $7 \mathbf{b}$ with a cyano group (MIC $1 \mathrm{mg} / \mathrm{mL}$ ). Different compounds permitted growth of M. lysodeikticus and S. aureus (isolate), with MIC values ranging from 0.38 to $0.50 \mathrm{mg} / \mathrm{mL}$. Schiff-base' inhibitory potential was very similar to compounds $\mathbf{3 b}, \mathbf{4 b}$ and $\mathbf{8 b}$, for all of bacteria, regardless of differences in structure. It is interesting, regarding the $S$. aureus results after $48 \mathrm{~h}$, that with an increase of the HOMO values of the synthesized compounds from most negative (- 9.67) to less (-9.37), the MIC values decreased. It was concluded that coumarin derivatives acting as electrophilic agents have a positive effect and inhibited bacterial growth [35,36]. Similar MICs were obtained for M. lysodiekticus. A LUMO decrease resulted in a MIC increase, with the exception of compound $\mathbf{6 b}$, as result of the better coumarin derivative penetration in bacterial cells in the absence of coumarin molecule nucleophilic action $[35,36]$. 
E. coli was also tested as an example of Gram negative bacteria, and only compounds $\mathbf{6 b}$ and $\mathbf{7 b}$ permitted growth after $24 \mathrm{~h}$. For the rest of the applied compounds the MIC was $0.13 \mathrm{mg} / \mathrm{mL}$. Results showed that after $48 \mathrm{~h}$ the best drug for Gram positive bacteria (6b) was the worst one for Gram negative. After $48 \mathrm{~h}$, the minimum inhibitory concentration of compound $\mathbf{6 b}$ was two to four times higher within Gram negative than Gram positive bacteria. Also, the earlier mentioned relationship between HOMO, LUMO and MIC was the opposite for E. coli, but that was expected due to differences in the chemical constitution of Gram positive and negative bacteria cell walls and the different mechanisms of coumarin penetration in bacteria cells [35,36].

Analysis further showed that only compounds $\mathbf{4 b}$ and $\mathbf{7 b}$ allowed growth of C. albicans after $24 \mathrm{~h}$. While compounds $\mathbf{1}, \mathbf{8 b}$ and $\mathbf{1 3 b}$ still prevented the growth of fungus at a concentration of 0.13 $\mathrm{mg} / \mathrm{mL}$, after 48 hours, the rest of the tested drugs showed a lack of inhibitory action, which is very interesting due to similarity of their structure. That was conformation that, in general, derivatives with carboxyl, ester or cyano group, presented slightly lower drug potential than acetyl-substituded ones.

Finally, the $p$-nitrophenylimino derivative of coumarin is a completely different pharmacophore, containing with two planar systems (Figure 4), and p-nitro group attached on imino ring. For all tested cultures of bacteria the final MIC was the same: $0.5 \mathrm{mg} / \mathrm{mL}$. That indicates that mechanism of interaction with bacteria is very similar. Also, compound $\mathbf{1 3 b}$ is very powerful growth inhibitor of fungus.

\subsection{Cylinder plate diffusion method}

The results of diffusion antimicrobial activity results are presented in Table 5 .

Table 5. Cylinder plate diffusion method $(\mu \mathrm{g} / \mathrm{mL})$ of synthesized derivatives.

\begin{tabular}{|c|c|c|c|c|c|c|c|c|c|c|c|c|c|c|c|}
\hline \multirow{3}{*}{\multicolumn{2}{|c|}{ Time (h) }} & \multicolumn{14}{|c|}{ Cultures $^{a}$} \\
\hline & & \multicolumn{2}{|c|}{$\mathrm{I}$} & \multicolumn{2}{|c|}{ II } & \multicolumn{2}{|c|}{ III } & \multicolumn{2}{|c|}{ IV } & \multicolumn{2}{|c|}{$\mathrm{V}$} & \multicolumn{2}{|c|}{ VI } & \multicolumn{2}{|c|}{ VII } \\
\hline & & 24 & 48 & 24 & 48 & 24 & 48 & 24 & 48 & 24 & 48 & 24 & 48 & 24 & 48 \\
\hline Comp. & Conc. $(\mu \mathrm{g} / \mathrm{mL})$ & \multicolumn{14}{|c|}{ Zones of inhibition $(\mathrm{mm})^{\mathrm{b}, \mathrm{c}, \mathrm{d}}$} \\
\hline 1 & 75 & 15 & 16 & 10 & 10 & 8 & 8 & 6 & 7 & 17 & 17 & 10 & 12 & 26 & 30 \\
\hline \multirow{2}{*}{$10 \mathrm{~b}$} & 75 & 1 & 1 & 1 & 1 & 1 & 1 & 1 & 1 & 1 & 1 & 1 & 1 & 1 & 1 \\
\hline & 150 & 1 & 1 & 1 & 1 & 1 & 1 & 1 & 1 & 1 & 1 & 1 & 1 & 1 & 1 \\
\hline \multirow{2}{*}{$13 b$} & 75 & 1 & 1 & 1 & 1 & 1 & 1 & 1 & 1 & 1 & 1 & 1 & 1 & 22 & 23 \\
\hline & 150 & 1 & 1 & 1 & 1 & 1 & 1 & 1 & 1 & 1 & 1 & 1 & 1 & 30 & 37 \\
\hline $16 \mathrm{~b}$ & 75 & 12 & 13 & 15 & 16 & 1 & 1 & 7 & 8 & 16 & 16 & 8 & 10 & 20 & 25 \\
\hline Antibioti & 10 & 26 & 24 & 20 & 19 & 24 & 25 & 52 & 53 & 24 & 23 & 21 & 21 & 26 & 23 \\
\hline
\end{tabular}

a I S. aureus; II S. aureus (isolate); III M. lysodiecticus,;IV K. pneumonia; V B. subtilis, VI E. coli; VII C. albincans; ${ }^{\mathrm{b}}$ (/) means absence of an inhibition zone; the results are from experiments run in triplicate, $\mathrm{SD}= \pm 3 \mathrm{~mm}$; ${ }^{\mathrm{c}}$ ethanol solvent controls were negative; ${ }^{\mathrm{d}}$ Standards were tetracycline $(10 \mathrm{mg} / \mathrm{mL})$ and ketoconazole $(10 \mathrm{mg} / \mathrm{mL})$.

Disc diffusion values for all tested microorganism were in the range $75-150 \mu \mathrm{g} / \mathrm{mL}$. Only compound 1 and selected Schiff bases have been tested as possible drugs by this method. The main 
result of the experiment is that compound $\mathbf{1 3 b}$ at a concentration of $150 \mu \mathrm{g} / \mathrm{mL}$ presented better inhibitory potential than applied antibiotic for C. albicans $(30-37 \mathrm{~mm})$. This molecule, with two planar systems [31-34] and a p-nitro group (Figure 5) has a great effect on fungus cell wall [37] and, therefore, totally lack of fungus resistance. It is very interesting that compound $\mathbf{1 0 b}$ with very similar structure but without a $p$-nitro group, showed complete lack of inhibitory activity for all tested cultures.

According to our test results, only compound $\mathbf{1}$ demonstrated inhibitory potential for all tested cultures within 24 hours of testing. When testing was performed on C. albicans, the inhibition zone of compound 1 was similar to that of $\mathbf{1 3 b}$. All examined microorganisms were sensitive to the presence of compound 16b, except M. lysodiecticus. Measured zones of inhibition, both for Gram positive and Gram negative bacteria, showed that compounds $\mathbf{1}$ and $\mathbf{1 6 b}$ are less effective than applied antibiotics. These compounds have no subtitution or an $n$-pentanoic acid moiety as substituent.

The tested cultures of bacteria showed notable resistance to the other compounds at the applied concentrations. It appears that only those compounds with free carbonyl or carboxyl groups present some growth inhibitory potential in 6-20 mm range within 24 and 48 hours. In general, the less sensitive culture was $K$. pneumoniae (Gram negative); and the most sensitive one was B. subtilis (Gram positive). Results for the fungus were very different. The behavior of compounds $\mathbf{1}$ and $\mathbf{1 6 b}$ was similar and they both stopped the growth of C. albicans, but the measured inhibition zones were larger than with tested bacteria, and conclusion is that the fungus was more sensitive to these compounds.

The general antimicrobial activity of natural coumarins has been documented in woodruff (Galium odoratum) extract [33]; the MIC values of some natural coumarins against Gram positive bacteria were $62.5 \mathrm{~g} / \mathrm{mL}-125 \mathrm{~g} / \mathrm{mL}$, suggesting that phenyl chain of position 8 and hydroxyl group at position 7 of the benzene ring are required for activity against $E$. coli and $S$. aureus. The antifungal potential of coumarins can be related to the presence of an alkyl group at the C-8 position and the MIC for these compounds for C. albicans was about $250 \mathrm{~g} / \mathrm{mL}$ [34]. Planarity of the coumarin ring makes penetration in Gram positive bacteria easier, but other factors such as shape have to be considered as well [31-34]. Coumarins proved to be slightly less active against Gram negative bacteria, due possibility to particular physical properties [31] (and in agreement with the results seen here).

\section{Experimental}

\subsection{Chemistry}

The sequence of the reactions used for the synthesis of the novel 4-hydroxychromene-2-one derivatives is outlined in Scheme 1. Compounds $\mathbf{2 b - 8 b}$ had been synthesized by Knoevenagel condensation using both conventional and fast microwave procedures. Different carbonyl, ester and cyano derivatives were used in the condensations with 4-hydroxychromene-2-one to achieve structural variety in the produced coumarins. Synthesis of compounds $\mathbf{9 b - 1 5 b}$ presents easy preparation of coumarin Schiff-base derivatives, also by two methods of preparation. The goal of synthesis was preparation of both aromatic and aliphatic 4-hydroxy-chromene-2-one derivatives and theirs characterization as potential antimicrobial agents. Both methods are simple with short reaction times and high yields. 
Scheme 1. Reaction of Condensation of 3-acetyl-4-hydroxy-chromene-2-one (1) with carbonyl compounds 2a-8a and amines 9a-16a (A. Conventional method; B. Microwave method).

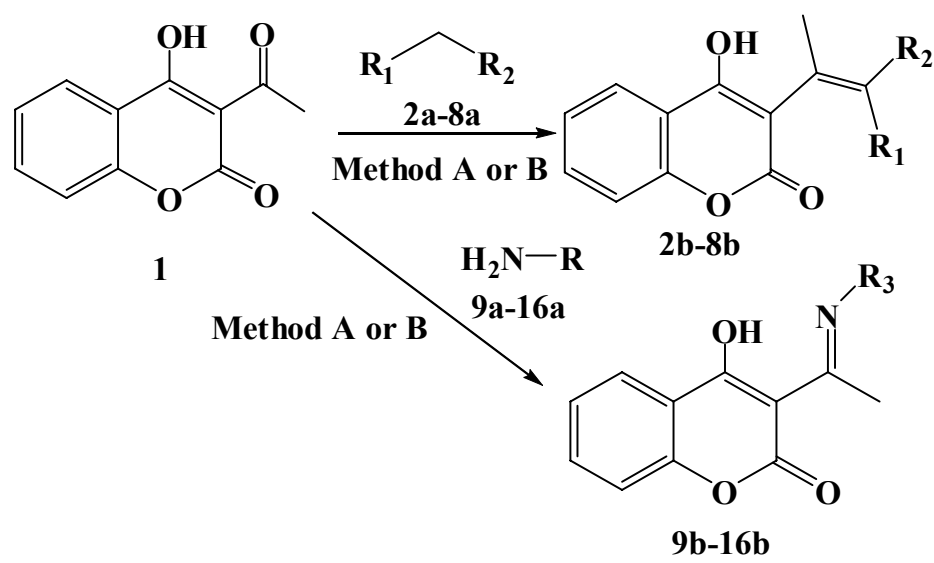

\subsection{Molecular Descriptors}

Geometries of the compounds were refined by three different semi-empirical methods: PM3 from Mopac 2000 [28], version 11 (Chem 3D v9, 2006) with gradient norm 0.100; PM5 method from CAChe WorkSystem Pro 6.01 software, and Minimize Energy method from Spartan 2002 for Windows. List of the descriptors is presented in Table 2. Also, in Table 3 we present side chain atom angles and dihedral angles for the compounds, calculated and optimized with Spartan 2002 tools. Figures with PM5 geometries of selected compounds were taken by CAChe software.

\subsection{Microbiology}

\subsubsection{Culture of Microorganisms}

Test bacteria used in this experiment were: Staphylococcus aureus (ATCC 25925), Staphylococcus aureus (clinical isolate, IHP), Escherichia coli (ATCC 25922), Micrococcus lysodeikticus (ATCC 4698) and Candida albicans (ATCC 10259), Bacillus subtilis (clinical isolate, IHP), Klebsiela pneumoniae (clinical isolate, IHP). All tested bacteria and fungi C.albicans were obtained from Laboratory for Microbiology, Faculty of Chemistry, University of Beograd, Serbia, and the Laboratory for Microbiology, from Institute for Health Protection (IHP) in Kragujevac.

\subsubsection{Minimal Inhibitory Concentration}

The antimicrobial activity of synthesized coumarins was measured using the microdilution method in Mueller-Hinton broth [38, 39]. The microdilution method was performed using a $24 \mathrm{~h}$ old culture of bacteria (and $48 \mathrm{~h}$ old culture of C. albicans) which was reseeded on the nutrient broth at a temperature of $37^{\circ} \mathrm{C}$. The inoculums were made and concentrations were adjusted with sterile water to $5.6 \times 10^{6} \mathrm{CFU} / \mathrm{mL}$ for bacteria and $3 \times 10^{4} \mathrm{CFU} / \mathrm{mL}$ for fungus. A series of two-fold dilutions of the coumarins, ranging from $4 \mathrm{mg} / \mathrm{mL}$ to $0.125 \mathrm{mg} / \mathrm{mL}$, was prepared in Mueller-Hinton broth with the addition of $0.1 \mathrm{~mL}$ of bacterial (yeast) suspensions. A set of tubes containing only inoculated broth was kept as a control. Tetracycline and ketoconazole were used as the control drugs. MICs were 
determined as the lowest concentration of the compounds that inhibited visible growth, and by the changing color of Resazurin solution $(0.02 \mathrm{~mL}$ of $0.05 \%$ concentration) from blue to pink [40].

\subsubsection{Disc diffusion Cylinder Plate Method}

Muller Hinton Agar (for bacteria) and Sabouraud dextrose agar (for yeast) were prepared with the addition of $1 \mathrm{~mL}$ of microbial suspension $\left(6.5 \times 10^{6} \mathrm{CFU} / \mathrm{mL}\right.$ for bacteria and $3 \times 10^{4} \mathrm{CFU} / \mathrm{mL}$ for yeast) and the plates incubated at $37^{\circ} \mathrm{C}$ for approximately $20 \mathrm{~min}$. Then sterile vertical cylinders were placed on the Petri dishes and samples of compounds $(75 \mu \mathrm{g} / \mathrm{mL}$ and $150 \mu \mathrm{g} / \mathrm{mL}$ in ethanol) were aseptically poured into the vertical cylinder using micropipettes [41-44]. The plates were subsequently incubated for 24 hours at $37^{\circ} \mathrm{C}$ for bacteria and 48 hours at $28^{\circ} \mathrm{C}$ for yeast. The diameter of zones of inhibition was measured in $\mathrm{mm}$. The standard antibiotics were tetracycline for bacteria and ketoconazole for C. albicans.

\subsection{Instruments and apparatus}

All reagents, solvents and catalyst were of analytical grade and used directly. All the melting points were recorded on a Kofler-hot stage apparatus (C. Reichert, Vienna, Austria) and uncorrected. The purity of compounds was checked routinely by TLC using a Merck Kieselgel $60 \mathrm{PF}_{254+366}$ and a Merck Kieselgel G. and spots were visualized by exposing the dry plates in iodine vapors. Also, the purity was checked by gas-chromatography/mass spectrometry. The IR spectra were run on a Perkin-Elmer Grating Spectrophotometers Model 137 and Model 337 in $\mathrm{cm}^{-1}$ (Perkin Elmer, Beaconsfield, UK). The NMR spectra were recorded on a Varian Gemini 200 spectrometer $\left({ }^{1} \mathrm{H}\right.$ at $200 \mathrm{MHz}$; Varian Inc., Palo Alto, CA, USA), in $\mathrm{CDCl}_{3}$ as solvent, using TMS ( $\left.\mathrm{SiMe}_{4}\right)$ as the internal standard. Chemical shifts are given in ppm, abbreviations: s-singlet, d-doublet, t-triplet, q-quartet, $\mathrm{ABq}-\mathrm{AB}$ quartet, $\mathrm{m}$ multiplet. Microanalysis of carbon, hydrogen, and nitrogen was carried out with a Carlo Erba 1106 microanalyser (Carlo Erba, Milan, Italy). GC/MS were carried out in Agilent 6890N/5975B gas chromatograph. The microwave assisted reactions were carried out in a MICROSYNTH Microwave Synthesis System (serial number: 130486, terminal: T640, serial number: 0804000100), manufactured by Milestone Inc. 25 Controls Dr. Shelton, CT 06484, USA [the microwaves are generated by a magnetron (serial number: 133462/13346), at the frequency of $2450 \mathrm{MHz}$ having an output energy range of 100-500 watts]. This apparatus is well suited for stringent reaction conditions, namely, anhydrous atmosphere, controlled temperature (using a fiber optic as an individual sensor for temperature control) and attachment of reflux condenser with constant stirring.

\subsection{Preparation of 3-acetyl-4-hydroxy-chromene-2-one derivatives (general procedure)}

3.5.1. Knoevenagel condensation of 3-acetyl-4-hydroxy-chromene-2-one (1) with carbonyl compounds 2a-8a

\subsubsection{Method A - Conventional procedure}

A solution of 3-acetyl-4-hydroxychromene-2-one $(1,2.5 \mathrm{mmol})$ and toluene $(50 \mathrm{~mL})$ containing a catalytic amount of ammonium acetate was taken and carbonyl compound 2a-8a was added. The 
reaction mixture was stirred for a period of $8 \mathrm{~h}$ at the boiling point of the solvent with azeotropic removal of water formed. The excess solvent was distilled off and solid product was filtered, dried, purified via column chromatography (benzene-acetone $=8: 2$ ) to give products $\mathbf{2 b - 8 \mathbf { b }}$.

\subsubsection{Method B - Microwave method}

A well ground mixture of a 3-acetyl-4-hydroxychromene-2-one (1, $2.5 \mathrm{mmol})$, carbonyl compound 2a-8a $(2.8 \mathrm{mmol})$ and ammonium acetate (catalytic amount) was irradiated and heated in the microwave reactor at the power setting and for the time indicated in Table 1. At the end of exposure to microwaves, the reaction mixture was cooled to room temperature, and the crude product was recrystallized from methanol to afford the coumarin derivatives $\mathbf{2 b - 8 b}$ (Scheme 1, Table 1).

\subsubsection{Condensation of 3-acetyl-4-hydroxy-chromene-2-one (1) with amines 9a-16a}

\subsubsection{Method A - Conventional method}

A mixture of 3-acetyl-4-hydroxychromene-2-one (1, $0.01 \mathrm{~mol})$, amine 9a-16a (0.01 mol) and a catalytic amount of $p$-toluenesulfonic acid in toluene $(50 \mathrm{~mL})$ was heated with azeotropic removal of water for a period of 10-12 h. Progres od reaction was monitored by TLC (toluene-acetone = 7:3). At the end of the reaction, the solvent was removed under reduced pressure. The solid products were filtered, dried and recrystallized from methanol to give compounds $\mathbf{9 b - 1 6 b}$.

\subsubsection{Method B - Microwave method}

A catalytic amount of $p$-toluenesulfonic acid was added to a toluene solution $(50 \mathrm{~mL})$ of equimolar amounts $(0.01 \mathrm{~mol})$ of 3-acetyl-4-hydroxychromene-2-one (1) and amine 9a-16a. The mixture was heated under microwaves for 3 minutes. After cooling, the solvent was removed, and the obtained solid was filtered and recrystallized from methanol (Table 1, Scheme 1).

\subsection{Spectral data of synthesized coumarin derivatives}

Diethyl 2-(1-(4-hydroxy-2-oxo-2H-chromen-3-yl)ethylidene)malonate (2b): Yield: 96\%; m..p. 224-226 ${ }^{\circ} \mathrm{C}$; IR $\left(\mathrm{KBr}, \mathrm{cm}^{-1}\right): v_{(\mathrm{OH})} 3434, v_{(\mathrm{CH} 3}$ and $\left.\mathrm{CH} 2\right) 2949$ and 2841, $v_{(\mathrm{C}=\mathrm{O})} 1731$ (lactone and ester), $v_{(\mathrm{C}=\mathrm{C}) \text { ar }}$, 1611, 1546 and 1496, $v_{(\mathrm{C}-\mathrm{O}-\mathrm{C})} 1368$ and 1032; ${ }^{1} \mathrm{H}-\mathrm{NMR}(\delta \mathrm{ppm}): 1.23\left(\mathrm{~m}, 6 \mathrm{H}, \mathrm{CH}_{3}\right.$, mixture of $\mathrm{Z}$ and $E$ isomers), 4.21 (q, 4H, 4CH ), 7.31-7.83 (m, 4H, H-5, H-6, H-7, H-8), 16.73 (bs, $1 \mathrm{H}, \mathrm{OH}-4)$; MS: m/z (\%): $346\left(\mathrm{M}^{+}\right)$; Anal. for $\mathrm{C}_{18} \mathrm{H}_{18} \mathrm{O}_{7}$ (346.33) (\%): C: 62.42, H: 5.24; found C: 62.44, H: 5.23.

Methyl 2-acetyl-3-(4-hydroxy-2-oxo-2H-chromen-3-yl)but-2-enoate (3b): Yield: 97\%; m.p. 237-239 ${ }^{\circ} \mathrm{C}$; IR $\left(\mathrm{KBr}, \mathrm{cm}^{-1}\right): v_{\mathrm{OH}} 3433, v_{(\mathrm{CH} 3)}, 2948,2930,2856, v_{(\mathrm{C}=\mathrm{O})} 1730$ (lactone and ester), $v_{(\mathrm{C}=\mathrm{O})} 1700$, $v_{(\mathrm{C}=\mathrm{C}) \text { ar }}$ 1610, 1545, 1495 1369, $v_{(\mathrm{C}-\mathrm{O}-\mathrm{C})} 1032$ and 1024; ${ }^{1} \mathrm{H}-\mathrm{NMR}(\delta \mathrm{ppm}): 2.20\left(\mathrm{~s}, 3 \mathrm{H}, \mathrm{CH}_{3}\right), 2.26$ (s, $3 \mathrm{H}, \mathrm{CO}-\mathrm{CH}_{3}$ ), 3.81 (s, 3H, COO-CH 3 ), 7.29-7.83 (m, 4H, H-5, H-6, H-7, H-8), 17.01 (bs, 1H, OH-4); MS: m/z (\%): $302\left(\mathrm{M}^{+}\right)$; Anal. for $\mathrm{C}_{16} \mathrm{H}_{14} \mathrm{O}_{6}$ (302.28) (\%): C: 63.57, H: 4.67; found C: 63.55, H: 4.71. 
Methyl 3-(4-hydroxy-2-oxo-2H-chromen-3-yl)but-2-enoate (4b): Yield: 96\%; m.p. 202-203 ${ }^{\circ} \mathrm{C}$, m.p. 222-223 ${ }^{\circ} \mathrm{C}$; IR $\left(\mathrm{KBr}, \mathrm{cm}^{-1}\right): v_{(\mathrm{OH})} 3422, v_{(\mathrm{CH} 3)} 2949,2930, v_{(\mathrm{C}=\mathrm{O})} 2841,1729$ (lactone and ester), $v_{(\mathrm{C}=\mathrm{C}) \mathrm{ar}}$ 1609, 1542, 1491, $v_{(\mathrm{C}-\mathrm{O}-\mathrm{C})} 1364,1033,1023 ;{ }^{1} \mathrm{H}-\mathrm{NMR}$ ( $\left.\delta \mathrm{ppm}\right): 2.22$ (s, 3H, $\left.\mathrm{CH}_{3}\right), 3.86$ (s, 3H, COO$\left.\mathrm{CH}_{3}\right), 5.76(\mathrm{~s}, 1 \mathrm{H}, \mathrm{C}=\mathrm{C}-\mathrm{H}), 7.29-7.82(\mathrm{~m}, 4 \mathrm{H}, \mathrm{H}-5, \mathrm{H}-6, \mathrm{H}-7, \mathrm{H}-8), 17.11$ (bs, 1H, OH-4); MS: m/z (\%): $260\left(\mathrm{M}^{+}\right)$; Anal. for $\mathrm{C}_{14} \mathrm{H}_{12} \mathrm{O}_{5}(260.24)(\%)$ : C: 64.61, H: 4.65; found C: 64.63, H: 4.69.

Methyl 2-cyano-3-(4-hydroxy-2-oxo-2H-chromen-3-yl)but-2-enoate (5b): Yield: 94\%; m.p. 247-249 ${ }^{\circ} \mathrm{C}$; IR $\left(\mathrm{KBr}, \mathrm{cm}^{-1}\right): v_{(\mathrm{OH})} 3434, v_{(\mathrm{CH} 3)} 2949,2929,2854, v_{(\mathrm{C}=\mathrm{N})} 2231, v_{(\mathrm{C}=\mathrm{O})} 1731$ (lactone and ester), $v_{(\mathrm{C}=\mathrm{C}) \text { ar }} 1611,1546,1497, v_{(\mathrm{C}-\mathrm{O}-\mathrm{C})} 1368,1032,1025 ;{ }^{1} \mathrm{H}-\mathrm{NMR}(\delta \mathrm{ppm}): 2.23\left(\mathrm{~s}, 3 \mathrm{H}, \mathrm{CH}_{3}\right), 3.80(\mathrm{~s}, 3 \mathrm{H}$, COO-CH ${ }_{3}$ ), 7.29-7.83 (m, 4H, H-5, H-6, H-7, H-8), 17.06 (bs, 1H, OH-4); MS: m/z (\%): $285\left(\mathrm{M}^{+}\right.$); Anal. for $\mathrm{C}_{15} \mathrm{H}_{11} \mathrm{NO}_{5}(285.06)(\%)$ : C: 63.16, H: 3.89, N: 4.91; found C: 63.18, H: 3.84, N: 4.95.

3-(1-(4-Hydroxy-2-oxo-2H-chromen-3-yl)-ethylidene)-pentane-2,4-dione (6b): Yield: 94\%; m.p. 241$243{ }^{\circ} \mathrm{C}$; IR $\left(\mathrm{KBr}, \mathrm{cm}^{-1}\right): v_{(\mathrm{OH})} 3434, v_{(\mathrm{CH} 3)} 2949,2929, v_{(\mathrm{C}=0)} 1731$ (lactone), $v_{(\mathrm{C}=0)} 1697,1686, v_{(\mathrm{C}=\mathrm{C}) \mathrm{ar}}$ 1610, 1544, 1496, v(C-O-C) 1371, 1032; ${ }^{1} \mathrm{H}-\mathrm{NMR}(\delta \mathrm{ppm}): 2.23\left(\mathrm{~s}, 3 \mathrm{H}, \mathrm{CH}_{3}\right), 2.29$ (s, 3H, CO-CH$)$, 7.31-7.83 (m, 4H, H-5, H-6, H-7, H-8), 17.01 (bs, 1H, OH-4); MS: m/z (\%): $286\left(\mathrm{M}^{+}\right)$; Anal. for $\mathrm{C}_{16} \mathrm{H}_{14} \mathrm{O}_{5}$ (286.28) (\%): C: 67.13, H: 4.93; found C: 67.15, H: 4.87.

2-Cyano-3-(4-hydroxy-2-oxo-2H-chromen-3-yl)but-2-enoic acid (7b): Yield: 84\%; m.p. 256-257 ${ }^{\circ} \mathrm{C}$; IR $\left(\mathrm{KBr}, \mathrm{cm}^{-1}\right): v_{(\mathrm{OH})} 3433$ (coumarin), $v_{(\mathrm{OH})} 3100(\mathrm{COOH}), v_{(\mathrm{CH} 3)} 2947,2927, v_{(\mathrm{C}=\mathrm{O})} 1731, v_{(\mathrm{C}=\mathrm{O})} 1699$ $(\mathrm{COOH}), v(\mathrm{C}=\mathrm{C})$ ar 1611,1543 ' 1495, $v_{(\mathrm{C}-\mathrm{O}-\mathrm{C})} 1371,1032 ;{ }^{1} \mathrm{H}$ NMR $(\delta \mathrm{ppm}): 2.24\left(\mathrm{~s}, 3 \mathrm{H}, \mathrm{CH}_{3}\right), 7.31-$ 7.83 (m, 4H, H-5, H-6, H-7, H-8), 12.37 (bs, 1H, COOH), 17.13 (bs, 1H, OH-4); MS: m/z (\%): 271 $\left(\mathrm{M}^{+}\right)$; Anal. for $\mathrm{C}_{14} \mathrm{H}_{9} \mathrm{NO}_{5}(271.22)(\%)$ : C: 62.00, H: 3.34, N: 5.16; found C: 62.05, H: 5.11, N: 5.21.

2-Acetyl-3-(4-hydroxy-2-oxo-2H-chromen-3-yl)but-2-enoic acid (8b): Yield: 87\%; m.p. 229-231 ${ }^{\circ} \mathrm{C}$; IR $\left(\mathrm{KBr}, \mathrm{cm}^{-1}\right): v_{(\mathrm{OH})} 3437$ (coumarin), $v_{(\mathrm{OH})} 3111(\mathrm{COOH}), v_{(\mathrm{CH})} 2991, v_{(\mathrm{C}=\mathrm{O})} 1727$ (lactone), $v_{(\mathrm{C}=\mathrm{O})}$ 1699, 1689 (COOH and keto group), $v(\mathrm{C}=\mathrm{C})_{\text {ar }} 1601,1541,1491, v_{(\mathrm{C}-\mathrm{O}-\mathrm{C})} 1369,1031 ;{ }^{1} \mathrm{H}-\mathrm{NMR}$ ( $\delta \mathrm{ppm}): 2.21\left(\mathrm{~s}, 3 \mathrm{H}, \mathrm{CH}_{3}\right), 2.28\left(\mathrm{~s}, 3 \mathrm{H}, \mathrm{CO}-\mathrm{CH}_{3}\right), 7.31-7.83$ (m, 4H, H-5, H-6, H-7, H-8), 12.65 (bs, $1 \mathrm{H}, \mathrm{COOH}$ ), 17.17 (bs, 1H, OH-4); MS: m/z (\%): $288\left(\mathrm{M}^{+}\right)$; Anal. for $\mathrm{C}_{15} \mathrm{H}_{12} \mathrm{O}_{6}$ (271.22) (\%): C: 62.50, H: 4.20; found C: 62.55, H: 4.21.

4-Hydroxy-3-(1-(phenylimino)ethyl)-2H-chromen-2-one (9b): Yield: 95\%; m.p. 169-171 ${ }^{\circ} \mathrm{C}$; IR (KBr, $\left.\mathrm{cm}^{-1}\right): v_{(\mathrm{OH})} 3415, v_{(=\mathrm{CHar})} 3073,3037, v_{(\mathrm{CH})} 2929,2853, v_{(\mathrm{C}=\mathrm{O})} 1704$ (lactone), $v_{(\mathrm{C}=\mathrm{N})} 1609$ (imino), $v_{(\mathrm{C}=\mathrm{C}) \text { ar }} 1592,1561,1480 ;{ }^{1} \mathrm{H}-\mathrm{NMR}(\delta \mathrm{ppm}): 2.72\left(\mathrm{~s}, 3 \mathrm{H}, \mathrm{CH}_{3}-\mathrm{C}=\mathrm{N}\right), 7.3(\mathrm{~m}, 1 \mathrm{H}, \mathrm{C}-6-\mathrm{H}), 7.4(\mathrm{dd}, 1 \mathrm{H}$, $\left.\mathrm{C}-8-\mathrm{H},{ }^{3} \mathrm{~J}_{8,7}=8.3 \mathrm{~Hz},{ }^{4} \mathrm{~J}_{8,6}=1.1 \mathrm{~Hz}\right), 7.6\left(\mathrm{dd}, 1 \mathrm{H}, \mathrm{C}-5-\mathrm{H},{ }^{3} \mathrm{~J}_{5,6}=7.8 \mathrm{~Hz},{ }^{4} \mathrm{~J}_{5,7}=1.7 \mathrm{~Hz}\right), 7.7(\mathrm{~m}, 1 \mathrm{H}, \mathrm{C}-7-\mathrm{H})$, 6.9-7.21 (m, 5H, phenyl), 16.15 (bs, 1H, OH-C-4); MS: m/z (\%): 279 (M+ 64), 278 (100), 264 (17), 262 (10), 250 (5), 236 (2), 234 (3), 222 (2), 188 (19), 187 (28), 158 (12), 144 (4), 131 (9), 130 (14), 121 (19), 118 (10), 93 (12), 92 (6), 77 (25), 65 (6), 51 (8); Anal. for $\mathrm{C}_{17} \mathrm{H}_{13} \mathrm{NO}_{3}$ (279.29) (\%): C: 73.11, H: 4.69, N: 5.02; found C: 73.09, H: 4.71, N: 4.97.

4-Hydroxy-3-(1-(p-tolylimino)ethyl)-2H-chromen-2-one (10b): Yield: 97\%; m.p. 147-149 ${ }^{\circ} \mathrm{C} . \mathrm{IR}(\mathrm{KBr}$, $\left.\mathrm{cm}^{-1}\right): v_{(\mathrm{OH})} 3421, v_{(=\mathrm{CHar},)} 3073, v_{(\mathrm{CH} 3)} 2985,2922,2852, v_{(\mathrm{C}=\mathrm{O})} 1709$ (lactone), $v_{(\mathrm{C}=\mathrm{N})} 1611$ (imino), 
$v_{(\mathrm{C}=\mathrm{C}) \text { ar }} 1597,1569,1513,1483 ;{ }^{1} \mathrm{H}-\mathrm{NMR}(\delta \mathrm{ppm}): 2.41\left(\mathrm{~s}, 3 \mathrm{H}, \mathrm{CH}_{3}-\mathrm{C}^{\prime}-3\right), 2.69\left(\mathrm{~s}, 3 \mathrm{H}, \mathrm{CH}_{3}-\mathrm{C}=\mathrm{N}\right)$, 7.09-7.65 $\left(\mathrm{AB}_{\mathrm{q}}, 4 \mathrm{H}\right.$, phenyl, ${ }^{3} \mathrm{~J}=8.43 \mathrm{~Hz} 7.3(\mathrm{~m}, 1 \mathrm{H}, \mathrm{C}-6-\mathrm{H}), 7.4\left(\mathrm{dd}, 1 \mathrm{H}, \mathrm{C}-8-\mathrm{H}, \mathrm{J}_{8,7}=8.3 \mathrm{~Hz}, \mathrm{~J}_{8,6}=1.1\right.$ $\mathrm{Hz}$ ), 7.6 (dd, 1H, C-5-H, J 5,6 $=7.8 \mathrm{~Hz}, \mathrm{~J}_{5,7}=1.7 \mathrm{~Hz}$ ), 7.7 (m, 1H, C-7-H), 16.07 (bs, 1H, OH-C-4); MS: m/z (\%): $293\left(\mathrm{M}^{+}, 91\right), 292$ (100), 278 (32), 276 (20), 264 (5), 236 (2), 188 (21), 187 (12), 172 (9), 158 (5), 145 (5), 144 (12), 132 (10), 121 (23), 107 (12), 106 (11), 91 (23), 77 (8), 65 (16), 51 (3); Anal. for $\mathrm{C}_{18} \mathrm{H}_{15} \mathrm{NO}_{3}$ (293.32) (\%): C: 73.71, H: 5.15, N: 4.78: found C: 73.72, H: 5.12, N: 4.79.

4-Hydroxy-3-(1-(m-tolylimino)ethyl)-2H-chromen-2-one (11b): Yield 94\%; m.p. 109-110 ${ }^{\circ} \mathrm{C} . \mathrm{IR}(\mathrm{KBr}$, $\left.\mathrm{cm}^{-1}\right): v_{(\mathrm{OH})}$ 3417, $v_{(=\mathrm{CH}) a r} 3067, v_{(\mathrm{CH} 3)} 2982,2929,2853, v_{(\mathrm{C}=\mathrm{O})} 1697$ (lactone), $v_{(\mathrm{C}=\mathrm{N})} 1606$ (imino), $v_{(\mathrm{C}=\mathrm{C}) \text { ar }}$ 1600, 1566, 1484; ${ }^{1} \mathrm{H}-\mathrm{NMR}(\delta \mathrm{ppm}): 2.42\left(\mathrm{~s}, 3 \mathrm{H}, \mathrm{CH}_{3}-\mathrm{C}^{\prime}-3\right), 2.70\left(\mathrm{~s}, 3 \mathrm{H}, \mathrm{CH}_{3}-\mathrm{C}=\mathrm{N}\right), 7.01(\mathrm{dd}$, $\left.1 \mathrm{H}, \mathrm{C}-4^{\prime}-\mathrm{H},{ }^{3} \mathrm{~J}_{4^{\prime}, 5},=7.58 \mathrm{~Hz},{ }^{4} \mathrm{~J}_{4^{\prime}, 6^{\prime}}=1.14 \mathrm{~Hz},\right), 7.04\left(\mathrm{dd}, 1 \mathrm{H}, \mathrm{C}-6{ }^{\prime}-\mathrm{H},{ }^{3} \mathrm{~J}_{6}, 5^{\prime}=8.12 \mathrm{~Hz},{ }^{4} \mathrm{~J}_{6}, 4^{,}=1.14 \mathrm{~Hz}\right)$, 7.12 (s, 1H, C-2'-H), 7.25 (dd, 1H, $\left.{ }^{3} \mathrm{~J}_{5^{\prime}, 4^{\prime}}=7.58 \mathrm{~Hz}, \mathrm{C}-5^{\prime}-\mathrm{H}^{3}{ }^{3} \mathrm{~J}_{5^{\prime}, 6}=8.12 \mathrm{~Hz}\right), 7.3$ (m, 1H, C-6-H), 7.4 $\left(\mathrm{dd}, 1 \mathrm{H}, \mathrm{C}-8-\mathrm{H},{ }^{3} \mathrm{~J}_{8,7}=8.3 \mathrm{~Hz},{ }^{4} \mathrm{~J}_{8,6}=1.1 \mathrm{~Hz}\right), 7.6\left(\mathrm{dd}, 1 \mathrm{H}, \mathrm{C}-5-\mathrm{H},{ }^{3} \mathrm{~J}_{5,6}=7.8 \mathrm{~Hz},{ }^{4} \mathrm{~J}_{5,7}=1.7 \mathrm{~Hz}\right), 7.7(\mathrm{~m}, 1 \mathrm{H}$, C-7-H), 15.9 (bs, 1H, OH-C-4); MS: m/z (\%): 293 (M+, 81), 292 (100), 278 (30), 276 (12), 264 (3), 236 (3), 188 (14), 187 (27), 172 (11), 158 (7), 145 (13), 144 (12), 132 (10), 121 (19), 107 (12), 106 (6), 91 (20), 77 (9), 65 (15), 51 (4); Anal. for $\mathrm{C}_{18} \mathrm{H}_{15} \mathrm{NO}_{3}$ (293.32) (\%): C: 73.71, H: 5.15, N: 4.78; found C: $73.72, \mathrm{H}: 5.14, \mathrm{~N}: 4.79$.

4-Hydroxy-3-(1-(o-tolylimino)ethyl)-2H-chromen-2-one (12b): Yield 94\%; m.p. 138-139 ${ }^{\circ} \mathrm{C}$. IR (KBr, $\left.\mathrm{cm}^{-1}\right): v_{(\mathrm{OH})} 3466.94, v_{(=\mathrm{CH}) a r} 3072.51, v_{(\mathrm{CH} 3)} 2935.08,2856.34, v_{(\mathrm{C}=\mathrm{O})} 1711.85$ (lactone), $v_{(\mathrm{C}=\mathrm{N})} 1610.82$ (imino), $v_{(\mathrm{C}=\mathrm{C}) \mathrm{ar}}$ 1594.26, 1562.86, 1486.38; ${ }^{1} \mathrm{H}-\mathrm{NMR}(\delta \mathrm{ppm}): 2.30$ (s, 3H, $\left.\mathrm{CH}_{3}-\mathrm{C}-1{ }^{\prime}\right), 2.81\left(\mathrm{CH}_{3^{-}}\right.$ $\mathrm{C}=\mathrm{N}), 7.23\left(\mathrm{dd}, 1 \mathrm{H}, \mathrm{C}-6{ }^{\prime}-\mathrm{H},{ }^{3} \mathrm{~J}_{6},{ }^{,}=8.01 \mathrm{~Hz},{ }^{4} \mathrm{~J}_{6}, 4^{,}=1.12 \mathrm{~Hz}\right), 7.28\left(\mathrm{dd}, 1 \mathrm{H}, \mathrm{C}-3{ }^{\prime}-\mathrm{H},{ }^{3} \mathrm{~J}_{3^{\prime}, 4},=7.62 \mathrm{~Hz}\right.$, $\left.{ }^{4} \mathrm{~J}_{3}, 5,=1.11 \mathrm{~Hz}\right), 7.3(\mathrm{~m}, 1 \mathrm{H}, \mathrm{C}-6-\mathrm{H}), 7.4\left(\mathrm{dd}, 1 \mathrm{H}, \mathrm{C}-8-\mathrm{H},{ }^{3} \mathrm{~J}_{8,7}=8.3 \mathrm{~Hz},{ }^{4} \mathrm{~J}_{8,6}=1.1 \mathrm{~Hz}\right), 7.37$ (m, 1H, C-5' H), $7.6\left(\mathrm{dd}, 1 \mathrm{H}, \mathrm{C}-5-\mathrm{H},{ }^{3} \mathrm{~J}_{5,6}=7.8 \mathrm{~Hz},{ }^{4} \mathrm{~J}_{5,7}=1.7 \mathrm{~Hz}\right), 7.7$ (m, 1H, C-7-H), 15.8 (bs, 1H, OH-C-4); MS: m/z (\%): $293\left(\mathrm{M}^{+}, 42\right), 292$ (34), 278 (100), 188 (7), 187 (11), 172 (8), 158 (15), 145 (4), 144 (9), 132 (9), 121 (16), 107 (2), 106 (3), 91 (17), 77 (6), 65 (13), 51 (6); Anal. for $\mathrm{C}_{18} \mathrm{H}_{15} \mathrm{NO}_{3}$ (293.32) (\%): C: 73.71, H: 5.15, N: 4.78: found C: 73.75, H: 5.21, N: 4.73 .

4-Hydroxy-3-(1-(4-nitrophenylimino)ethyl)-2H-chromen-2-one (13b): Yield 92\%; m.p. 212-215 ${ }^{\circ} \mathrm{C}$. IR $\left(\mathrm{KBr}, \mathrm{cm}^{-1}\right): v_{(\mathrm{OH})} 3414, v_{(=\mathrm{CH}) a r} 3081,3046, v_{(\mathrm{CH} 3)} 2992,2947,2849, v_{(\mathrm{C}=\mathrm{O})} 1707$ (lactone), $v_{(\mathrm{C}=\mathrm{N})} 1608$ (imino), $v_{(\mathrm{C}=\mathrm{C}) \mathrm{ar}} 1580,1519,1483, v_{\mathrm{ar}(\mathrm{NO} 2)} 1557,1340 ;{ }^{1} \mathrm{H}-\mathrm{NMR}(\delta \mathrm{ppm}): 2.76\left(\mathrm{~s}, 3 \mathrm{H}, \mathrm{CH}_{3}-\mathrm{C}=\mathrm{N}\right), 7.3$ (m, 1H, C-6-H), 7.4 (dd, 1H, 8-H, $\left.\mathrm{J}_{8,7}=8.3 \mathrm{~Hz}, \mathrm{~J}_{8,6}=1.1 \mathrm{~Hz}\right), 7.43\left(\mathrm{~d}, 2 \mathrm{H},{ }^{3} \mathrm{~J}_{3^{\prime}, 2},{ }^{3} \mathrm{~J}_{5}, 6^{\prime}=8.9 \mathrm{~Hz}, 3^{\prime}-\mathrm{H}, \mathrm{C}-\right.$

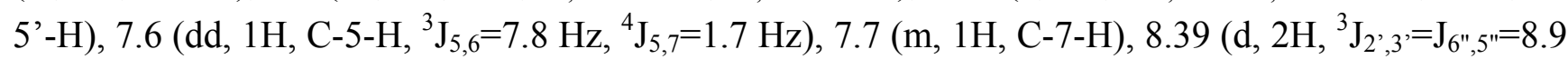
Hz, C-2'-H, C-6'-H), 15.95 (bs, 1H, OH-C-4); MS: m/z (\%): 324 (M+1, 60), 323 (100), 309 (8), 307 (10), 294 (14), 277 (18), 263 (8), 221 (1), 207 (7), 203 (6), 188 (26), 187 (47), 176 (6), 163 (9), 157 (9), 121 (48), 117 (12), 108 (7), 92 (14), 77 (9), 76 (13), 67 (14), 65 (12); Anal. for $\mathrm{C}_{17} \mathrm{H}_{12} \mathrm{~N}_{2} \mathrm{O}_{5}$ (324.29) (\%): C: 62.96, H: 3.73, N: 8.64: found; C: 62.97, H: 3.77, N: 8.69.

4-Hydroxy-3-(1-(3-nitrophenylimino)ethyl)-2H-chromen-2-one (14b): Yield: 97\%; m.p. 209-210 ${ }^{\circ} \mathrm{C}$. IR $\left(\mathrm{KBr}, \mathrm{cm}^{-1}\right): v_{(\mathrm{OH})} 3416, v_{(=\mathrm{CH}) a r} 3089,3062, v_{(\mathrm{CH} 3)} 2980,2936,2853, v_{(\mathrm{C}=\mathrm{O})} 1705$ (lactone), $v_{(\mathrm{C}=\mathrm{N})}$ 1609 (imino), $v_{(\mathrm{C}=\mathrm{C}) \text { ar }} 1590,1538,1491, v_{\mathrm{ar}(\mathrm{NO} 2)} 1562,1353 ;{ }^{1} \mathrm{H}-\mathrm{NMR}(\delta \mathrm{ppm}): 2.61\left(\mathrm{~s}, 3 \mathrm{H}, \mathrm{CH}_{3}-\mathrm{C}=\mathrm{N}\right)$, $7.26\left(\mathrm{dd}, 1 \mathrm{H}, 6^{\prime}-\mathrm{H}_{,} \mathrm{J}_{6^{\prime}, 5}=8.02 \mathrm{~Hz},{ }^{4} \mathrm{~J}_{6}, 4^{\prime}=1.12 \mathrm{~Hz}\right), 7.3(\mathrm{~m}, 1 \mathrm{H}, \mathrm{C}-6-\mathrm{H}), 7.34$ (s, 1H, C-2'-H), 7.4 (dd, 
$\left.1 \mathrm{H}, \mathrm{C}-8-\mathrm{H},{ }^{3} \mathrm{~J}_{8,7}=8.3 \mathrm{~Hz},{ }^{4} \mathrm{~J}_{8,6}=1.1 \mathrm{~Hz}\right), 7.54\left(\mathrm{~m}, 1 \mathrm{H}, \mathrm{C}-5{ }^{\prime}-\mathrm{H}\right), 7.6\left(\mathrm{dd}, 1 \mathrm{H}, \mathrm{C}-5-\mathrm{H},{ }^{3} \mathrm{~J}_{5,6}=7.8 \mathrm{~Hz}\right.$, $\left.{ }^{4} \mathrm{~J}_{5,7}=1.7 \mathrm{~Hz}\right), 7.7(\mathrm{~m}, 1 \mathrm{H}, \mathrm{C}-7-\mathrm{H}), 8.09\left(\mathrm{dd}, 1 \mathrm{H}, \mathrm{C}-4{ }^{\prime}-\mathrm{H}^{3}{ }^{3} \mathrm{~J}_{4,5^{\prime}}=8.5 \mathrm{~Hz},{ }^{4} \mathrm{~J}_{4^{\prime}, 6^{\prime}}=1.12 \mathrm{~Hz}\right), 16.02(\mathrm{bs}, 1 \mathrm{H}$, OH-C-4); MS: m/z (\%): 324 (M+ 69), 323 (83), 307 (100), 294 (14), 263 (61), 249 (3), 234 (3), 220 (3), 207 (7), 188 (26), 187 (67), 176 (6), 163 (15), 157 (12), 145 (5), 138 (5), 130 (8), 121 (78), 117 (19), 103 (9), 92 (27), 77 (15), 76 (29), 67 (25), 65 (18), 51 (6); Anal. for $\mathrm{C}_{17} \mathrm{H}_{12} \mathrm{~N}_{2} \mathrm{O}_{5}$ (324.29) (\%): C: 62.96, H: 3.73, N: 8.64: found: C: 62.96; H: 3.73; N: 8.64.

3-(1-(Benzylimino)ethyl)-4-hydroxy-2H-chromen-2-one (15b): Yield 97\%; m.p. 151-152 ${ }^{\circ} \mathrm{C}$. IR (KBr, $\left.\mathrm{cm}^{-1}\right): v_{(\mathrm{OH})} 3406, v_{(=\mathrm{CH}) \text { ar }} 3032,3012, v_{(\mathrm{CH} 2)} 2930, v_{(\mathrm{C}=\mathrm{O})} 1698$ (lactone), $v_{(\mathrm{C}=\mathrm{N})} 1612$ (imino), $v_{(\mathrm{C}=\mathrm{C}) \mathrm{ar}}$ 1586, 1572, 1485; ${ }^{1} \mathrm{H}-\mathrm{NMR}(\delta \mathrm{ppm}): 2.64\left(\mathrm{~s}, 3 \mathrm{H}, \mathrm{CH}_{3}-\mathrm{C}=\mathrm{N}\right), 3.95$ (t, 2H, $\left.\mathrm{CH}_{2}-\mathrm{N}=\mathrm{C}\right), 7.29$ (m, 2H, C'-

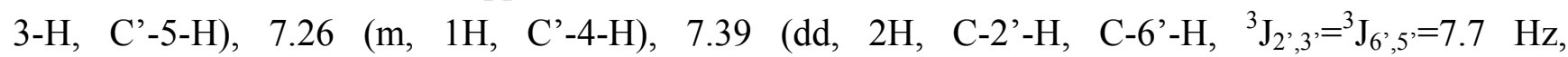
$\left.{ }^{4} \mathrm{~J}_{2},{ }^{,},={ }^{4} \mathrm{~J}_{6}, 4,=1.1 \mathrm{~Hz}\right), 7.3(\mathrm{~m}, 1 \mathrm{H}, \mathrm{C}-6-\mathrm{H}), 7.4\left(\mathrm{dd}, 1 \mathrm{H}, \mathrm{C}-8-\mathrm{H},{ }^{3} \mathrm{~J}_{8,7}=8.3 \mathrm{~Hz},{ }^{4} \mathrm{~J}_{8,6}=1.1 \mathrm{~Hz}\right), 7.6(\mathrm{dd}, 1 \mathrm{H}$, $\left.\mathrm{C}-5-\mathrm{H},{ }^{3} \mathrm{~J}_{5,6}=7.8 \mathrm{~Hz},{ }^{4} \mathrm{~J}_{5,7}=1.7 \mathrm{~Hz}\right), 7.7$ (m, 1H, C-7-H), 16.01 (bs, 1H, OH-C-4); MS: m/z (\%): 293 $\left(\mathrm{M}^{+}, 100\right), 292$ (14), 276 (15), 262 (2), 236 (3), 202 (66), 189 (6), 173 (10), 156 (19), 144 (14), 131 (9), 121 (16), 107 (12), 106 (6), 91 (20), 77 (9), 65 (15), 51 (4); Anal. for $\mathrm{C}_{18} \mathrm{H}_{15} \mathrm{NO}_{3}$ (293.32) (\%): C: 73.71, H: 5.15, N: 4.78; found C: 73.73; H: 5.13; N: 4.73.

5-(1-(4-Hydroxy-2-oxo-2H-chromen-3-yl)ethylideneamino)pentanoic acid (16b): Yield 87\%; m.p. 169-171 ${ }^{\circ} \mathrm{C}$; IR $\left(\mathrm{KBr}, \mathrm{cm}^{-1}\right): v_{(\mathrm{OH})} 3418$ (coumarin), $v_{(\mathrm{OH})} 3602-2811(\mathrm{COOH}), v_{\left(\mathrm{CH}_{3}, \mathrm{CH}_{2}\right)} 2947,2930$, 2875, $v_{(\mathrm{C}=\mathrm{O})} 1721(\mathrm{COOH}), v_{(\mathrm{C}=\mathrm{O})} 1703$ (lactone), $v_{(\mathrm{C}=\mathrm{N})} 1614$ (imino), $v_{(\mathrm{C}=\mathrm{C}) \text { ar }} 1600,1560,1487 ;{ }^{1} \mathrm{H}-$

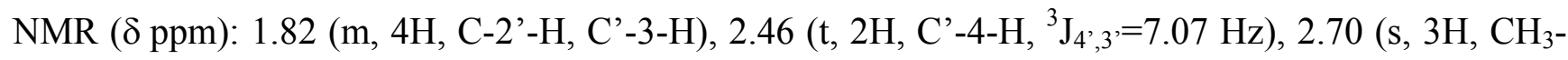
$\mathrm{C}=\mathrm{N}), 3.60$ (t, 2H, C'-1-H, $\left.{ }^{3} \mathrm{~J}_{1,2},=7.1 \mathrm{~Hz}\right), 7.3(\mathrm{~m}, 1 \mathrm{H}, \mathrm{C}-6-\mathrm{H}), 7.4\left(\mathrm{dd}, 1 \mathrm{H}, \mathrm{C}-8-\mathrm{H},{ }^{3} \mathrm{~J}_{8,7}=8.3 \mathrm{~Hz}\right.$, $\left.{ }^{4} \mathrm{~J}_{8,6}=1.1 \mathrm{~Hz}\right), 7.6\left(\mathrm{dd}, 1 \mathrm{H}, \mathrm{C}-5-\mathrm{H},{ }^{3} \mathrm{~J}_{5,6}=7.8 \mathrm{~Hz},{ }^{4} \mathrm{~J}_{5,7}=1.7 ; \mathrm{MS}: \mathrm{m} / \mathrm{z}(\%)=303\left(\mathrm{M}^{+}\right)\right.$; Anal. for $\mathrm{C}_{16} \mathrm{H}_{17} \mathrm{NO}_{5}(303.11)(\%): \mathrm{C}: 63.36 ; \mathrm{H}: 5.65 ; \mathrm{N}: 4.62$; found C: 63.27; H: 5.68; N: 4.63.

\section{Conclusions}

New coumarin derivatives have been synthesized using conventional and microwave heating methodology and characterized. The advantages in the use of microwave methodology are shorter reaction times, higher yields and simplified work up procedures for the point of purification of the prepared compounds. All tested compounds are in principal very good potential microorganism growth inhibitors, but their structural diversity resulted in great differences in inhibitory potential. Finally, a nice result of this experiment is that we have synthesized some compounds that have varied and different influence on different classes of bacteria and the fungus C. albicans.

\section{Acknowledgements}

This study was financially supported by a Grant No 142025 from the Serbian Ministry of Science. 


\section{References}

1. Lovell, D.P.; Iersel, M.V.; Walters, D.; Price, R.J.; Lake, B.G. Genetic variation in the metabolism of coumarin in mouse liver. Pharmacogenetics 1999, 9, 239-250.

2. Gregory, J.F.; Emma, K.; Bernadette, S.C.; Denise, A.E. In vitro cytotoxic potential and mechanism of action of selected coumarins, using human renal cell lines. Cancer Lett. 2002, 183, 61-68.

3. Kirkiacharian, S.; Thuy, T.; Sicsic, S.; Bakhchinian, R.; Kurkjian, R.; Tonnaire, T. Structureactivity relationships of some 3-substituted-4-hydroxycooumarins as HIV-1 protease inhibitors. Farmaco 2002, 57, 703-708.

4. Lafitte, D.; Lamour, V.; Tsvetkov, P.; Markov, A.A.; Deprez, M.; Klich, P.; Moras, D.; Briand, C.; Gilli, R. DNA gyrase intgeraction with coumarin-based inhibitors-the role of the hydroxybenzoate isopentenyl moiety and the 5'-methyl group of the noviose. Biochemistry 2002, 41, 7217-7223.

5. Hurry, R.G.; Cortz, C.; Ananthanaraxan, T.P.; Schmolka, S. A new coumarin synthesis and its utilization for the synthesis of polycyclic coumarin compounds with anticarcinogenic properties. J. Org. Chem. 1998, 53, 3936-3943.

6. Traykova, M.; Kostova, I. Coumarin Derivatives and Oxidative Stress. Int. J. Pharm. 2005, 1, 2932.

7. O'Kennedy, R.; Thornes, R.D.; Richard, O.K.; Douglas, T.R. Coumarins: Biology, Applications and Mode of Action, John Wiley and Sons, Chichester, UK, 1977.

8. Zahradnik, M. The Producton and Application of Fluorescent Brightening Agents; John Wiley and Sons: New York, NY, USA, 1992.

9. Maeda, M. Laser Dyes; Academic Press: New York, USA, 1994.

10. Kostova, I. Syntetic and natural coumarins as cytotoxic agents, Curr. Med. Chem. Anticancer Agents 2005, 5, 29-46.

11. Giguere, R.J.; Bray, T.L.; Duncan, S.M.; Majetich, G. Application of commercial microwave ovens to organic synthesis. Tetrahedron Lett. 1986, 27, 4945-4948.

12. Gedye, R.; Smith, F.; Westaway, H.; Ali, H.; Baldivera, L.; Laberge, L.; Rousell, The use of microwave ovens for rapid organic synthesis. Tetrahedron Lett. 1986, 27, 279.

13. Ambramovitch, R. A. Applications of microwave energy in organic chemistry. A review. Org. Prep. Proc. Int. 1991, 23, 683.

14. Bose, A.K.; Manhas, M.S.; Ghost, M.; Raju, V.S.; Tabei, K.; Urbanczyk-Lipowska, Z. Examination of the Perkin Reaction under Microwave Irradiation, Heterocycles 1990, 30, 741.

15. Villemin, D.; Ben Alloum, A. Potassium fluoride on alumina: condensation of 3-methyl-2-thiono-4thiazolidinone with aldehydes. Synthesis of $\alpha$-thioacrylic acids phosphonothionothiazolidinones. Phosph. Sulf. Silic. 1993, 79, 33.

16. Puciová, M.; Ertl, P.; Toma, S. Synthesis of ferrocenyl-substituted heterocycles: the beneficial effect of the microwave irradiation. Collect. Czech Chem.Commun. 1994, 59, 175.

17. Lácová, M.; Chovancová, J.; Veverková, E.; Toma, Š. Microwaves assisted Gabriel synthesis of phthalides. Tetrahedron 1996, 52, 14995-15006. 
18. Hamelin, J.; Bazureau, J.P.; Texier-Boullet, F.; Loupy, A. Microwaves in Organic Synthesis; Wiley-VCH: Weinheim, 2002; p. 253.

19. Besson, T.; Brain, C.T.; Lidström, P.; Tierney, J.P. Microwave-Assisted Organic Synthesis; Blackwell Publishing: Oxford, 2004; p. 44.

20. Kappe C.O.; Stadtler A. Microwaves in Organic and Medicinal Chemistry; Wiley-CH: Weinheim, 2005.

21. Vukovic, N.; Sukdolak, S.; Solujic, S.; Milosevic, T. Synthesis and antimicrobial evaluation of some novel 2-aminothiazole derivatives of 4-hydroxy-chromene-2-one. Arch. Pharm. 2008, 341, 491-496.

22. Sukdolak, S.; Solujić, S.; Vuković, N.; Manojlović, N.; Krstić, Lj. Synthesis of 3-(thiazol-4-yl)-4hydroxycoumarins. J. Serb. Chem. Soc. 2004, 69, 319-326.

23. Sukdolak, S.; Solujić, S.; Manojlović, N.; Vuković, N.; Krstić, Lj. Hantzsch reaction of 3-(2bromoacetyl)-4-hydroxy-chromen-one. J. Heterocycl. Chem. 2004, 41, 593-596.

24. Sukdolak, S.; Vuković, N.; Solujić, S.; Milošev, M.; Manojlović, N.; Krstić, Lj. Synthesis of new 3-(2-aminothiazol-4-yl)-4-hydroxy-chromen-2-one derivatives. J. Serb. Chem. Soc. 2006, 71, 6.

25. Vuković, N.; Sukdolak, S.; Solujić, S.; Manojlović, N.; Krstić, Lj. Synthesis of some 3-(2aminothiazol-4-yl)-4-hydroxycoumarins. In Proceedings of the XVIII Congress of Chemists and Technologists of Macedonia, Ohrid, 2004; OCB-15.

26. Vuković, N.; Sukdolak, S.; Solujić, S.; Manojlović, N.; Krstić, L. Synthesis of 3-(thiazol-4-yl)-4hydroxy Coumarins. Book of Abstracts of the $4^{\text {th }}$ International Conference of the Chemical Societes of the Sout-East Europian Countries. 1 Belgrade, 2004; GT-P 139.

27. Bram, G.; Loupy, A.; Villemin, D. Solid Supports and Catalysts in Organic Chemistry. Ellis Harwood: London, UK,1992.

28. Software Mopac 2000, version 11. ChemOffice Ultra, 2006; Cambridge software, 2006.

29. Software CAChe WorkSystem Pro 6.01. Textronix WorkSystem, 2003.

30. Software Spartan 2002 for Windows. Wavefunction, Inc., USA, 2002.

31. Kayser, O.; Koldrziey, H. Antibacterial activity of simple coumarins structural requirements for biological activity. Z. Naturforch. 1999, 54c, 169-174

32. Rauchman, B.S.; Tidwell, M.X.; Johnson, J.V.; Roth, B. 2,4,diamino-5-benzyl-pirimidines and analogues as antibacterial agents. J. Med, Chem. 1989, 32, 1927-1935

33. Ojala, T.; Remes, S.; Haansuu, P.; Vuorela, H.; Hiltunen, R.; Haahtela, K.; Vuorela, P. Antimicrobial activity of some coumarin containing herbal plants growing in Finland. $J$. Ethnopharm. 2006, 73, 299-305.

34. Montagner, C.; de Souza, S.; Groposoa, C. Delle Monache, F.; Smania, E.; Smania, A. Antifungal activity of coumarins. J. Biosci. 2008, 63, 21-28.

35. Elinos-Báez, C.M.; Leon, F.; Sants, E. Effects of coumarin and 7OH-coumarin on bcl-2 and Bax expression in two human lung cancer cell lines in vitro. Cell Biol. Int. 2005, 29, 703-708.

36. Duncana, S.H.; Flinta, H.J.; Stewarta, C.S. Inhibitory activity of gut bacteria against Escherichia coli O157 mediated by dietary plant metabolites. FEMS Microbiol. Letters 2006, 164, 283-288.

37. Teles, H.L.; Sordi, R.; Silva, G.H.; Castro-Gamboa, I.; da Silva Bolzani, V.; Pfenning, L.H.; Magalhães de Abreu, L.; Costa-Neto, C.M.; Young, M.C.M.; Araújo, Â.R. Aromatic compounds 
produced by Periconia atropurpurea, an endophytic fungus associated with Xylopia aromatic. Phytochemistry 2006, 67, 2686-2690

38. NCCLS. Performance standards for antimicrobial susceptibility testing $14^{\text {th }}$ Int. Suplement M100-S14. Wayne, PA, USA, 2003.

39. Umesha, S; Richardson, P.A.; Kong, P. Hong, C.X. A novel indicator plant to test the hypersensitivity of phytopathogenic bacteria. J. Microbiol. Meth. 2008 , 72, 95-97.

40. Carter, C.H.; Gaspar, A.J.; Leise, J.M. Resazurin staining of bacterial colonies on membranes filters. Fort Dietrick: Frederick, Maryland, USA, 1955.

41. Beena, J.; Akhila, R.; Emilia, A. Antimicrobial activity and chemical composition of essential oil from Hedychium coronarium. Phytother. Res. 2007, 21, 439-443.

42. Massada, Y. Analysis of essential oil by gas chromatography and spectrometry. Wiley: New York, USA, 1976.

43. BSAC. Disc Diffusion Method for Antimicrobial Susceptibility Testing, Version 4, January 2005.

44. CLSI. Performance Standards for antimicrobial Disc Susceptibility Tests Approved StandardTenth Edition, M02-A10, Wayne, PA, 2009.

Sample Availability: Samples of the compounds $\mathbf{2 b - 1 5 b}$ are available from the authors.

(C) 2009 by the authors; licensee Molecular Diversity Preservation International, Basel, Switzerland. This article is an open-access article distributed under the terms and conditions of the Creative Commons Attribution license (http://creativecommons.org/licenses/by/3.0/). 